\title{
Sport marketing and non profit marketing - perfect together
}

\author{
David Shani ${ }^{1}$
}

Published online: 18 June 2015

(C) Springer-Verlag Berlin Heidelberg 2015

The sector is referred to by many names: non for profit sector, the social sector, the philanthropy sector, the do good sector to name just a few. While there is no agreement about the proper name, there is an agreement that the sector is growing in size and importance, and accounts for a significant size of many countries economies across the globe. Its growing size and complexity resulted in a push to make the participating organization more "business like" by adopting tools, methods and best practices of business organizations.

Jim Collins the author of Good to Great, added a short monograph to the iconic book-Good To Great and the Social Sector. In his view the most important area nonprofit needs to "adopt" from the for profit sector is marketing or more specific brand management. In his words: “.. Whereas in business, the key driver in the flywheel is the link between financial success and capital resources, I'd like to suggest that a key link in the social sectors is brand reputation-built upon tangible results and emotional share of heart so that potential supporters believe not only in your mission, but in your capacity to deliver on that mission." This growing realization that brand building is crucial for the ability of the non-profit organization to fund and deliver on its mission, should lead such organizations to adopt and use for profit brand building practices.

It is well established that an effective way to build a sustainable brand reputation is by engaging in sports marketing (Gwinner 1997; Gwinner and Eaton 1999; Smith et al. 2008; Stipp 1998). As the field of sports marketing evolved, a significant body of research was created to understand better the various elements of sports marketing and how to use them effectively. However, most of these efforts were focused on for profit sector. Very little effort was made to study and adopt what we learnt about sports marketing to the nonprofit and public sector. The exception might be the subject of country image and sport (Florek et al. (2008), Gibson et al. (2008), Green et al. 2003),

David Shani

dshani@kean.edu

1 MBA in Global Management, Global Business School, Kean University, Union, NJ, USA 
Nebenzahl et al. (1991), Wonjun et al. (2009)). This focus is, perhaps, because the mega-events requires a large investment of public money and need to be justified. Furthermore, sports and in particular the more visible professional sports are connected with big money, the bad behavior of athletes and continuous high visibility corruption cases like the latest corruption case involving FIFA. This is not the kind of industry non profit organization will like to be involved with. However, a significant portion of sports and nonprofit activities are done at the grass root level. Thus, one would expect to see more efforts to understand the synergies of sports marketing and non profit marketing at that level "well below" the global mega events.

This special issue proves that point. While the call for papers didn't call for any specific type of sports marketing activities, most of the contributions were for work done with e grass root or local sports events and nonprofit organizations. Perhaps, signaling that there are much more research efforts on the synergy of sports marketing and nonprofit at the grass root level and local sports events, and not only at the international or national mega sport events. Overall, the response was encouraging. We received many more manuscripts than we anticipated. Given the high quality of the submissions it was not easy to arrive to the final selection. I tried to include articles that are not only high quality, but also demonstrate the variety of situations and types of research on the subject: the lead article explores the usage and perceived effectiveness of social media within intercollegiate athletics departments. The findings point to the interesting discrepancy in the use of social media among nonprofit sports organizations. While social media are used extensively to raise awareness and support, marketing objectives, it is under utilized as for fundraising and volunteer recruitment.

In the second article, the authors use mixed methods research design that consisted of two studies: qualitative followed by quantitative to explore the stakeholder identities, and how these identities are related to the support, development and their future intentions. It provides some specific suggestions how a grassroots sporting event can be an effective tool for NPOs and sport marketers to create a connection with consumers and their community.

The interconnections between sport programs, corporate social responsibility, social entrepreneurship and the creation of social capital at the community level is the focus of the third article. The results of this small scale empirical study (one of the few empirical studies on the subject), is that the reasons that lead companies to support/sponsor, sports projects with outcomes of increased social capital at community level is more complex interrelated, and not so obvious. The authors conclude by providing some practical implications for managers of sport organizations with community interventions; and for companies that support this type of initiative.

In the call for papers I made the point that sports marketing and non profit are similar in that, both are about inspiration, people giving above and beyond, and unique stories. That's why decided to include the fourth paper. It is different from all the other papers in the special issue, as it is not focusing on the integration of sports marketing and nonprofit. It rather explores the fans purchase intention of a newly created local sport team. I made a decision to include it, as I believe in strong similarities of the "purchase intentions" of a sports fan and NPO supporters. Thus, the strong theoretical approach of the paper and the findings can be also applicable to any new non profit cause or organization that is struggling to create a donor or participants support base. 
At the beginning of the editorial I mentioned the importance of brand reputation and management for the sustainable growth of a nonprofit organization. The fifth paper focuses more on that subject. More specifically on brand valuation of nonprofit, non-governmental organizations (NGOs). The research utilizes the resource based view (RBV) of the firm, to develop a framework of how intercollegiate athletic programs(nonprofit) can determine their brand equity. The study utilizes the fees paid by rights holders to broadcast intraconference as a significant predictor of the value of individual football programs to athletic conferences. The authors advance the idea, that given that broadcast rights for intercollegiate teams are bought and sold on the free market by bids of for profit entities (e.g. ESPN ,FOX). The incremental fees they add to their conference can serve as an appropriate way to measure the team brand value. I am convinced that the paper is making an important contribution to the literature as is. However, our challenge is to extend and develop the approach for other nonprofit organizations that might not be involved in any broadcasting deals. Such an approach can provide a nonprofit organization with a way to demonstrate their brand value to a corporation that they are looking to collaborate with.

The last paper is more typical to the kind of research in the area. It focuses on an interesting case study and application in using sports activities to achieve nonprofit organization objectives. However the paper takes somewhat a different approach in assessing the effective collaboration between a sport organization and a health care organization. It explores the impact of corporate social marketing by a professional sport organization with the objective of an health care organization initiative. The study evaluates a 12-week familycentered health promotion initiative delivered by a U.S. professional sport organization. While small in scale, the study suggests how sport organizations can contribute to health promotion at the community level through a family unit-centered initiative.

Taken all together, the special issue provides an interesting look at various approaches in creating a much needed bridge between sports marketing and NPOs. Most likely it creates many more questions than providing answers. However, as such, I hope it will be a a solid base and a springboard for much needed research on the subject.

\section{References}

Florek, M., Breitbarth, T., \& Cojejo, F. (2008). Mega event = Mega impact? Travelling fans' experience and perceptions of the 2006 FIFA World Cup host nation. Journal of Sport and Tourism, 13(3), 199-219.

Gibson, H.J., Qi, G.X., \& Zhang, J.J. (2008). Destination image and intent to visit China and the 2008 Beijing Olympic Games. Journal of Sport Management, 22, 427-450.

Green, B.C., Costa, C.A., \& Fitzgerald, M. (2003). Marketing the host city: analyzing exposure generated by a sport event. International Journal of Sports Marketing and Sponsorship, 5(4), 335-353.

Gwinner, K.P. (1997). A model of image creation transfer in event sponsorship. International Marketing Review, 14, 145-58.

Gwinner, K.P., \& Eaton, J. (1999). Building brand image through event sponsorship: the role of image transfer. Journal of Advertising, 28(4), 47-57.

Nebenzahl, I.D. \& Jaffe, E.D. (1991). The effectiveness of sponsored events in promoting a country's image. International Journal of Advertising 10, 223-237.

Smith, A., Graetz, B., \& Westerbeek, H. (2008). Sports sponsorship, team support and purchase intentions. Journal of Sports Marketing Communications, 14(5), 387-404.

Stipp, H. (1998). The impact of olympic sponsorship on corporate image. International Journal of advertising, $17(1), 75-87$.

Wonjun, C., \& Chang, W. (2009). The effects of hosting an international sports event on a host country: the 2008 summer olympic games. International Journal of Sports Marketing and Sponsorship, 12(4), 281-300. 